\title{
Evaluation of tissue dissolution ability of modified chlorhexidine as a root canal irrigant
}

\author{
Samira Shahsiah ${ }^{1}$, Arash Azizi ${ }^{2 *}$, Eskandar Moghimipour ${ }^{3}$, Paul V. Abbott ${ }^{4}$, \\ Kasra Karamifar ${ }^{5}$, Mansour Jafarzadeh ${ }^{6}$ and Mina Fazeli ${ }^{7}$ \\ ${ }^{1}$ Department of Endodontics, Faculty of Dentistry, Ahvaz Jundishapur University of Medical Sciences, Ahvaz, Iran \\ ${ }^{2}$ Oral medicine Department, Islamic Azad University,Dental Branch, Tehran, Iran \\ ${ }^{3}$ Medicinal Plant Research Center,Faculty of Pharmacy,Ahvaz Jundishapur University of Medical Sciences, \\ Ahvaz, Iran \\ ${ }^{4}$ Winthrop Professor of Clinical Dentistry,University of Western Australia, Australia \\ ${ }^{5}$ Department of Endodontics, Dental Branch, Shiraz Islamic Azad University, Shiraz, Iran \\ ${ }^{6}$ Department of Endodontics, Faculty of Dentistry, Ahvaz Jundishapur University of Medical Sciences, Ahvaz, Iran \\ ${ }^{7}$ Dentist
}

\begin{abstract}
The first and main goal of root canal treatment is the elimination of microorganisms from the contaminated root canal system and providing an environment for the healing of periapical tissues. Instrumentation alone cannoteffectivelyclean the complex root canal system. Souse of irrigantsalong mechanicalpreparationis required. But no single solution is able to fulfill these actions completely. Chlorhexidineis one of the substances thatis usedas anirrigantin endodontics. It has broadantimicrobialspectrum, but itdoes not have theability todissolveorganictissues. It has been shownthat theaddition ofsurfactantin thesolution can increasesthe abilityof dissolvetissue.In this in vitro study tissue-dissolving capacity of sodium hypochlorite (5/25\% and 2/5\%), chlorhexidine $(0 / 2 \%)$ and modified chlorhexidine (chlorhexidine + benzalkonium chloride and chlorhexidine + sodium lauryl solphate) were compared.Tissue samples prepared from bovine pulp and each of the samples immersed for 20 minutes in each test solution (changing the solution every 2 minutes).The sampleswereweighedbefore and aftertesting. The weight difference divided by the initial weight of the tissue sample, multiplied by 100, was defined as the percentage of tissue solubility.NaOCl 5/25\% was more solublethantheothersolutions. ExceptCHX $0 / 2 \%$ and salineno statistically significant differences was found between the tissuedissolving properties of othersolutions and $\mathrm{NaOCl} 5 / 25 \%$. The results of this study indicate that the use of $0 / 2 \% \mathrm{CHX}+2 \% \mathrm{SLS}$ as irrigant in endodontic can show similar effect with $\mathrm{NaOCl} 5 / 25 \%$ in the solubility.
\end{abstract}

KEY WORDS: ROOT CANAL THERAPY, CHLORHEXIDINE, TISSUE SOLABILITY, BENZALKONIUM CHLORIDE, SODIUM LAURYL SULPHATE

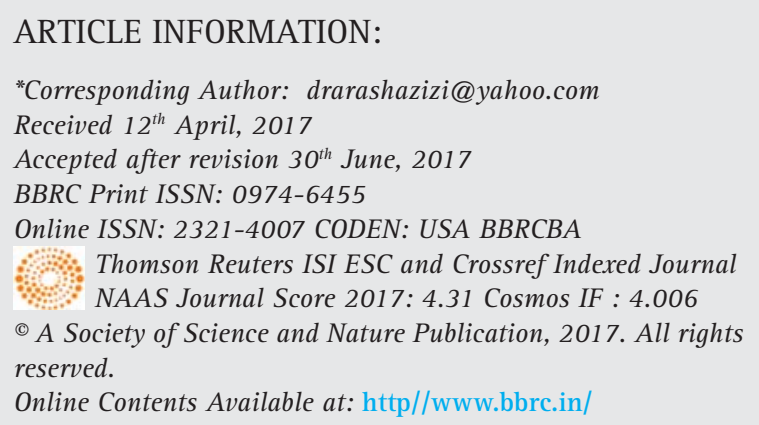




\section{INTRODUCTION}

Studies illustrated that different methods of using tools during cleaning and forming produces smear layer which covers dentinal tubule canal and inlet (Johnson W.T , et al, 2008; Belts R.E , et al, 2003). This layer diameter is $\mathrm{m} \mu 2-$ and it is disordered and formless (Karale $\mathrm{R}$ , et al, 2011). From Pulp organic ingredients and inorganic dentin debri, micro-organisms, their products and necrotic are formed (Johnson W.T , et al, 2008; Karale R , et al, 2011; Baumgartner J.C , et al, 2007; Belts R.E , et al, 2003). Smear layer presence avoids penetration of medicine in canal into root canal system and dentinal tubules and also prevents full compatibility of filling materials with surface of canal prepared walls (Belts et al, 2003).

Different acids, ultra sonic tools, and lasers are used for removing this layer (Belts et al, 2003). One material is Ethylene diaminete traacetic acid (EDTA). This chemical is part of chelator that has capacity of removing inorganic elements however cannot remove inorganic materials. So there is need to use a tissue solvent material such as $\mathrm{NaOCl}$. Recommended time for removing smear layer by EDTA is 1 minute. This material will cause pretubular and intratubular exceeding omission (Johnson et al, 2008). Generally, detergents are categorized as follow (Kandaswamy and Venkateshbabu 2010):

Sodium hypochlorite $(\mathrm{NaOCl})$ with density of 5/0$25 / 5 \%$ is the most prevalent detergent which is used for endodontic treatments (Karale et al, 2011; GuerreiroTanomaru 2011). $\mathrm{NaOCl}$ has different advantages including mechanical cleaning of debris of canal, capacity of solving alive tissues and necrotic, anti-microbial activity, blundering activity and long shelf-life. In addition, this cheap material is highly accessible (Johnson et al, 2008; Karale et al, 2011; Guerreiro-Tanomaru 2011). Popular density of $\mathrm{NaOCl}$ is 5/2\%in which tissue solubility and anti-microbial characteristics are maintained.
This density normally is used in teeth with necrotic pulp or apical priodentit (Johnson et al, 2008; GuerreiroTanomaru 2011).

$\mathrm{NaOCl}$ averagely is effective against bacteria but it has less effect against endotoxin in infected canals (Kandaswamy and Venkateshbabu 2010). It has also some restrictions in solving tissues due to limited contact with existing tissues in whole canal space (Johnson et al, 2008).Unfortunately using $\mathrm{NaOCl}$ has some disadvantage. This material is very toxic and creates severe inflammatory reaction in addition when it crosses the root apex accidentally; it produces severe pain, swelling and hematoma (Karale et al, 2011).

Chlorhexidine gluconate (CHX) is a mouth wash that is used in different densities as a detergent for endodontic treatment. CHX is a broad extent anti-microbial factor against gram-positive bacteria and gram-negative bacteria. This material has low toxic property and it is absorbed by dental tissue and mucous membrane, while its effective material is released slowly. Biocompatibility property and substantivity of CHX justifies clinical use of this material (Kandaswamy and Venkateshbabu 2010; Karale 2011; Guerreiro-Tanomaru 2011). Anti-microbial property of 2\% CHX is similar to $\mathrm{NaOCl} 25 / 5 \%$ while enterococcus faecalis is more effective (Johnson et al, 2008). One disadvantage of Chlorhexidine gluconate is lack of ability for solving necrotic tissue and removing smear-layer (Johnson et al, 2008; Kandaswamy and Venkateshbabu 2010) which may has effect on other properties of this material (Guerreiro-Tanomaru J.M, 2011).

Out of different materials, surfactant had acceptable solubility, because it has either Hydro philic or hydrophobe properties. This material is solved in hydro phase through hydrophilic property and it is solved via hydrophobo in organic phase and cause solution of present material in both phases. In addition, this mate-

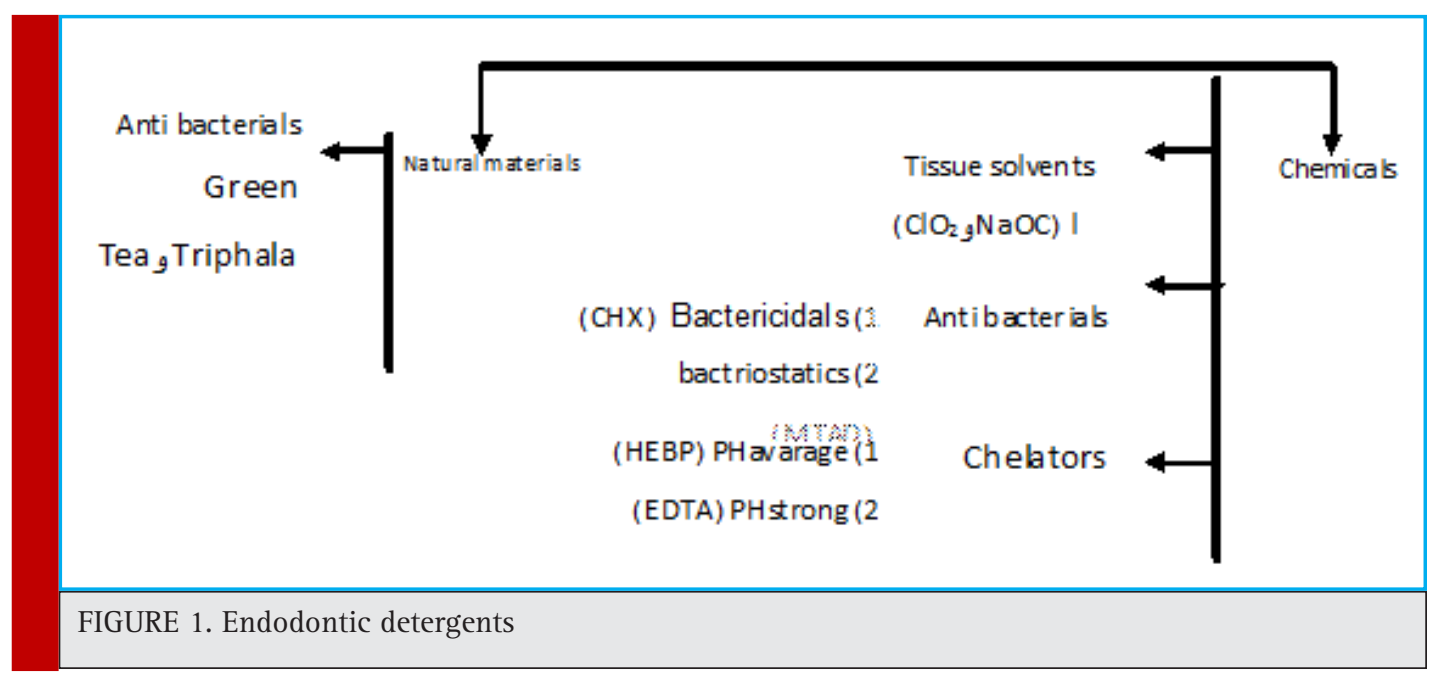


rial decreases surface tension of bacteria cell walls so it destroys them via which it implements anti-bacterial properties (Aulton and Taylor 2008).

According to disadvantage of $\mathrm{NaOCl}$ including toxicity and providing sever inflammatory reactions (Karale et al, 2011 ) and based on advantages of CHX including broad antimicrobial property, informality and biocompatibility, using CHX as detergent is more appropriate in endodontic treatment. However lack of ability of this material in solubility of remained tissues has caused limitation of its application. So adding one material with tissue solubility properties into CHX can handle this problem and it can provide a detergent with better properties.

Irrigation of root canal during root treatment is an important phase. There is no evidence that approved detergent type role in success of the treatment. So there is no agreement on what detergent is the best one or on what detergents are better if they are both used. However they all agree that the detergent need to have antimicrobial activity. The best result is obtained from using a good detergent with anti-bacterial activity when it contacts long enough with batteries of root canal system. This means that, for fulfilling preparation stage before obtuaration, detergent needs to be reached a sufficient volume during the treatment (Iqbal 2012). It seems that using local medicine is more effective and better that all applicable antibiotic plans (Martin 1991).

Irala et al (2010) in Luterana University in Brazil performed studies on different densities on $\mathrm{NaOCl}$ alone and also with combination of EDTA. Results indicated that combination of $\mathrm{NaOCl}$ with EDTA has no ability of tissue solution. T-test also indicated that $2 / 5 \% \mathrm{NaOCl}$ solve the tissue in less time than $1 \% \mathrm{NaOCl}$. On the other hand, solutions' PH were decreased in 48 hours. In addition, Cobankara et al in 2010 in Secuk univesristy of Turkey performed an experiment on Cobankara and chlorine dioxide. Studies illustrated that saline has no capacity of solving organic tissue. Both 25/5\% NaOCl and $8 / 13 \% \mathrm{ClO}_{2}$ solution more effectively solved pulp tissue in compare to control saline $(\mathrm{P}<0 / 05)$. On the other hand, no statistical difference between solubility capacity of $25 / 5 \% \mathrm{NaOCl}$ and $8 / 13 \% \mathrm{ClO}_{2}$ was observed. It was indicated that both materials have similar effect considering tissue solubility. In addition, Cbristensen et al (2008) in Alabama Birmingham University investigated effect of sodium hypochlorite PH decrease on its tissue solubility property. Statistical results did not show significant difference in groups with PH 12 and PH9. While there was significant difference in groups with $\mathrm{PH}$ 12 and PH 9 and group with PH6. Higher densities and longer durations caused increase of solubility.

In this study two surfactant including 4\% Benzalkonium and 2\% Sodium lauryl Sulfate have been studied.
General objective is study of tissue solubility of changed chlorhexidine in root cleaning. We aimed at answering following questions:

- How much is the weight loss percentage of pulp tissue after using 5.25\% $\mathrm{NaOCl}$ solution?

- How much is the weight loss percentage of pulp tissue after using $2.5 \% \mathrm{NaOCl}$ solution?

- How much is the weight loss percentage of pulp tissue after using $0.2 \%$ CHX solution?

- How much is the weight loss percentage of pulp tissue after using CHX + Benzalkonium chloride solution?

- How much is the weight loss percentage of pulp tissue after using CHX + Sodium lauryl sulfate solution?

- Are weight loss percentages of pulp tissue different in experimental groups?

At the following we explained materials and methods of collecting data and collecting samples. In section 3 we provided research results and statistical tests. After discussing the cases we provided final conclusion.

\section{MATERIALS AND METHODS}

In this study, in order to providing pulp samples, we used bovine mandible of one-year-old calf from slaughterhouse. Milkanseizure teeth were separated from mandible. There was germ on permanent anseizure tooth under these teeth which was accessible by mandible bone cleavage. Teeth pulp covered with thin skin of enamel was separated and It was kept in 40-c degree in central laboratory of Pharmacy department until experiment's time. Solutions of the experiment were prepared by an expert from laboratory of Pharmacy department who had no interference in. and he coded them from number 1 to 6 . The tester had no information of group codes and solution types. Solution lists are as follow: $\mathrm{NaOCl}$ 25/5\%,NaOCl 5/2\%,benzalkonium chloride 4\% CHX $+2 / 0 \%$, sodium lauryl sulfate $2 \% \mathrm{CHX}+2 / 0 \%$, CHX $2 / 0 \%, \mathrm{NaCl} 9 / 0 \%$ as a controller

During experiment, pulp samples were divided into sections with weight approximate to $25 \mathrm{mg}$. samples were categorized in 5 groups with 10 samples and one group with 5 samples as control group.Each sample weight was measured with digital scale before experiment. Sample was transferred to experiment tube and tube were coded. After preparation of samples, $2 \mathrm{ml}$ experiment solution was poured on pulp sample in experiment tube by syringe. And sample was place on vibrator for 2 minutes. After 2 minutes the solution was extracted by syringe from experiment tube. Then $2 \mathrm{ml}$ fresh solution was added to the sample and it was placed on vibrator for another two minutes. This process was performed for 
10 times for each sample. By this method, each sample had contact with fresh solution for 20 minutes. After 20 minutes, all solution was extracted by syringe from the tube and pulp sample was dried. Finally, weight of dry pulp sample was measured by the same digital scale and it was recorded.

This method was performed for each 6 group and the results were recorder. For calculating percentage of weight loss, weight difference of tissue sample before and after contact with solution under experiment was divided into initial weight of tissue and was multiplied in 100 (Zehnder M, 2006; Siqueira J.F, et al, 2009). In order to test obtain results, data summary was reported for average and standard deviation of $\mathrm{X}_{ \pm} \mathrm{SD}$ and in order to comparing groups we used one-way analysis and then we used post hoc for pairwise.

Based on before studies, there would be 10 samples in each group with $25 \mathrm{ml}$ weight (Kleier et al, 2008). In this study, 6 groups of solution were experimented. Tissue samples were washed with solutions. For calculating percentage of weight loss, weight difference of tissue sample before and after contact with solution under experiment was divided into initial weight of tissue and was multiplied in 100. Results are in table (1).

In addition, diagrams (1) to (6) represent percentage of tissue solubility in samples of group 1 to 6 . Solution with code number 1 which included 25/5\%sodium hypochlorite averagely indicated solubility percentage as 70/53\%. In this group, 6 samples show solubility percentage above $50 \%$ and 4 sample showed solubility percentage below $40 \%$.

Solution with code number 2 included 2/5\% sodium hypochlorite. Tissue solubility had $07 / 27 \%$ average while out of 10 samples one sample showed 50\% solubility, one sample showed negative solubility and other samples showed solubility under $50 \%$.. solution number 3 included chlorhexidine+ benzalkonium chloride showed average of 39/32\% tissue solubility and out of all sample one sample showed solubility above 50\% and other samples showed solubility below 50\%. In addition, solution number 4 included chlorhexidine+ $2 \%$ sodium dodecyl sulfates showed solubility average as $83 / 34 \%$ while all

\begin{tabular}{|l|l|l|}
\hline \multicolumn{3}{|l|}{ Table 1. solutions under experiment } \\
\hline $\begin{array}{l}\text { Sample } \\
\text { number }\end{array}$ & Solution name & $\begin{array}{l}\text { Solution } \\
\text { code number }\end{array}$ \\
\hline 10 & NaOCl 25/5\% & 1 \\
\hline 10 & NaOCl 5/2\% & 2 \\
\hline 10 & BKC 4\%+CHX 2/0\% & 3 \\
\hline 10 & SLS 2\%+CHX 2/0\% & 4 \\
\hline 10 & CHX 2/0\% & 5 \\
\hline 5 & NaCl 9/0\% & 6 \\
\hline
\end{tabular}

10 samples showed solubility below 40\%. However solution number 6 included normal saline which was used as control solution and showed average 66/0- \%tissue solubility. Out of 5 samples under study, 2 samples had solubility below $10 \%$, one sample zero solubility and 2 samples showed negative solubility.

\section{RESULTS AND DISCUSSION}

In comparing 6 groups, maximum solubility is related to $5 / 25 \%$ sodium hypochlorite and minimum solubility is related to $0 / 2 \%$ chlorhexidine which is after control group. After 5/25\% sodium hypochlorite, percentage of solubility is respectively related to chlorhexidine+ $2 \%$ sodium dodecyl sulfate, chlorhexidine+ $4 \%$ benzalkonium chloride and 2/5\% sodium hypochlorite.

In addition, descriptive statistic table for 6 groups is as follow:

Statistical analysis of ANOVA with 95\% as confidence level was performed by 6 groups. And $\mathrm{p}<0 / 05$ indiçâted that there is no signifiant différence $(\mathrm{P}=0 / 0)$.

In addition, in Hemogeneity of variances test $(\mathrm{P}<0.05)$, variance of 6 group, has significant difference $(\mathrm{P}=0.011)$.

For comparing average of 6 groups we used Welch test in which significant difference between groups was observed $(\mathrm{P}=.00)$.

For pairwise comparing of groups, Tamhane test was used. Results indicated that there is significant difference between group 1 (5/25\% sodium hypochlorite) with group 6 (normal saline) and group 5 (0/2\% chlorhexidine) group 3 (chlorhexidine+ benzalkonium chloride) with group 6, group 4 (sodium dodecyl sulfate) with group 6 and group 5 with group 6. It means that normal saline and chlorhexidine has no ability of solving organic tissue.

On the other hand, there is not significant difference between group 1 with group 2,3 and 4. It means that solubility of these groups is approximate to solubility of 5/25\% sodium hypochlorite.

Root treatment without operation is predictable method for tooth protection which is withdrawn in case of no treatment (Johnson et al, 2008). Initial etiologic factor in formation of pulp waste and priapical bacteria were studied (Kandaswamy and Venkateshbabu 2010; Guerreiro-Tanomaru et al, 2011; Martin 1991; Mohammadi and Abbott 2009, Portenier et al, 2002). Micro-organisms may be existed in root canal, dentinal tubules, secondary canals and apical strait (Kandaswamy and Venkateshbabu 2010;Baumgartner et al, 2007; Iqbal 2012). In some dentinal teeth, even DEJ was infected (Zehnder et al, 2003).

If cleaning is not performed appropriately, necrosis residuals of soft tissue is acting as feeding resource of 

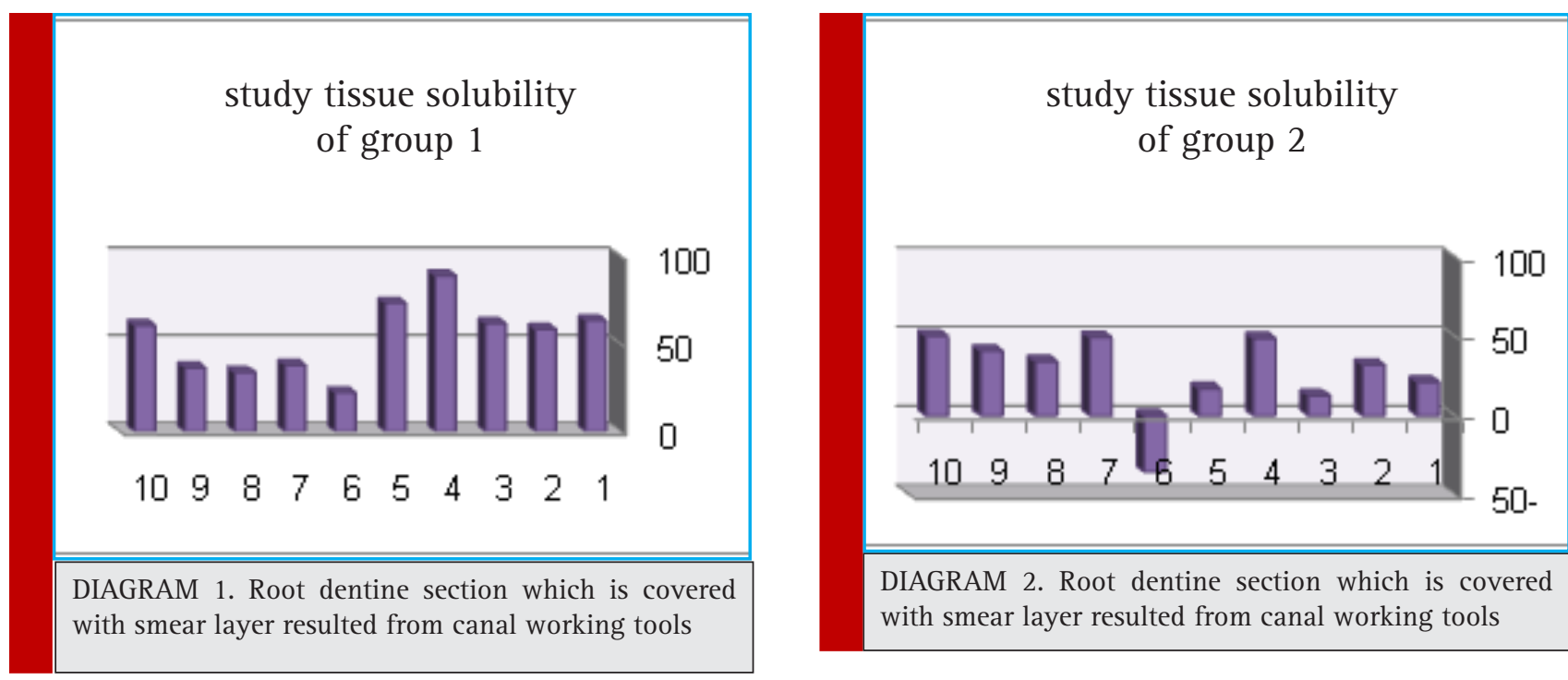

DIAGRAM 2. Root dentine section which is covered with smear layer resulted from canal working tools
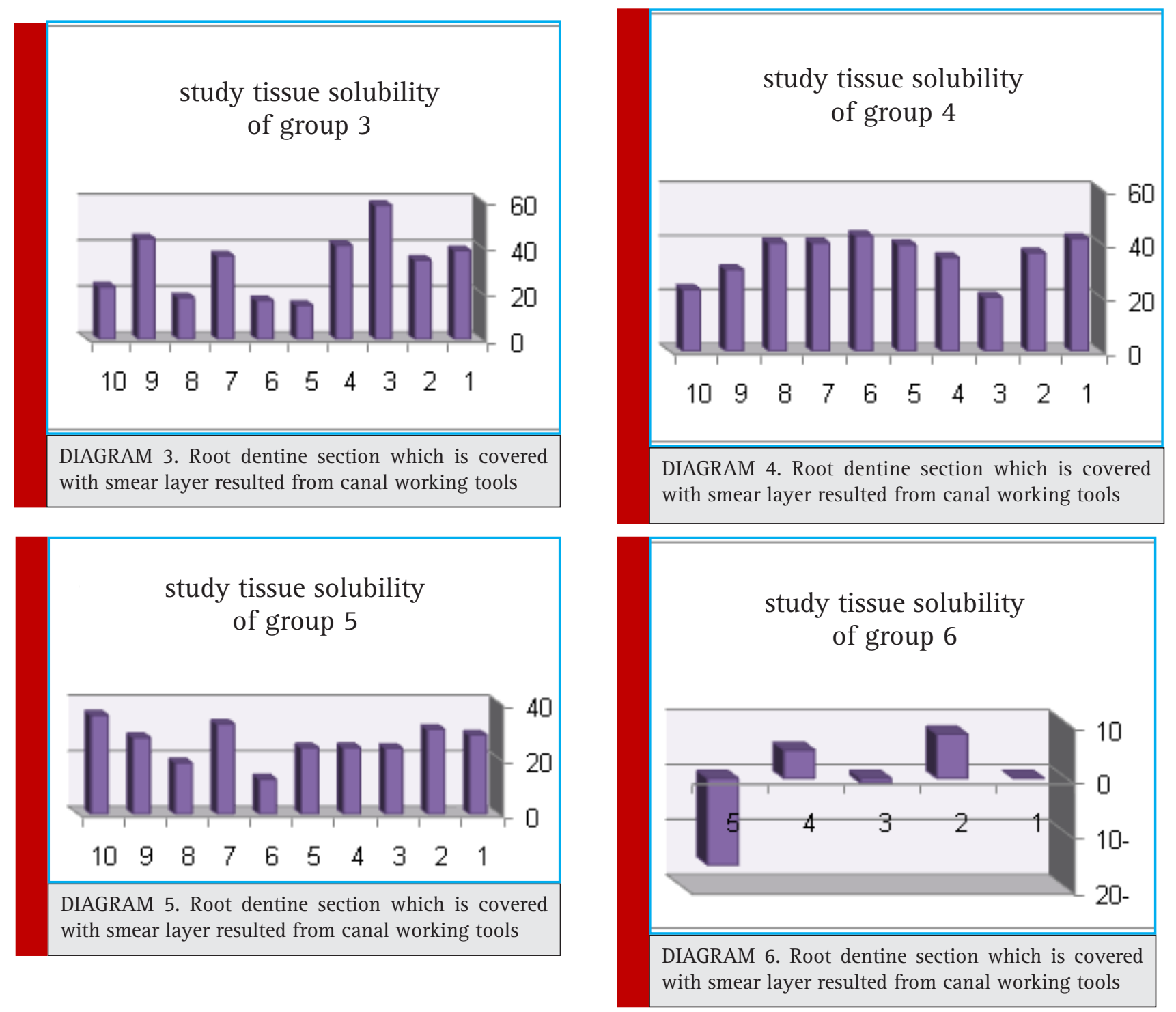


\begin{tabular}{|l|l|}
\hline \multicolumn{2}{l}{$\begin{array}{l}\text { Table } 2 . \text { average of tissue solubility } \\
\text { percentage of solutions under study }\end{array}$} \\
\hline $\begin{array}{l}\text { average of tissue } \\
\text { solubility }\end{array}$ & $\begin{array}{l}\text { SOLUTION UNDER } \\
\text { STUDY }\end{array}$ \\
\hline $70 / 53 \%$ & $\mathrm{NaOCl} 25 / 5 \%$ \\
\hline $07 / 27 \%$ & $\mathrm{NaOCl} 5 / 2 \%$ \\
\hline $39 / 32 \%$ & $\mathrm{BKC} \% \% \mathrm{CHX}+2 / 0 \%$ \\
\hline $83 / 34 \%$ & SLS 2\% CHX $+2 / 0 \%$ \\
\hline $61 / 25 \%$ & CHX 2/0\% \\
\hline $66 / 0-\%$ & normal saline \\
\hline
\end{tabular}

remained bacteria and can contaminate canal again (Torabinejad , et al, 2003; Sassone et al, 2008; Hariharan et al, 2010). Thus, first and most important aim in endodontic treatment is full elimination of microorganisms from root canal system and providing an environment for restoring per apical tissue Siqueira et al, 2009; Regan and Fleury 2006). Achieving this goal is possible with elimination of disease tissues and prevention from second pollution until root canal space is converted into a resource for infection (Rossi-Fedele et al, 2010; Vianna et al, 2009). Mechanical use of tools cannot effectively

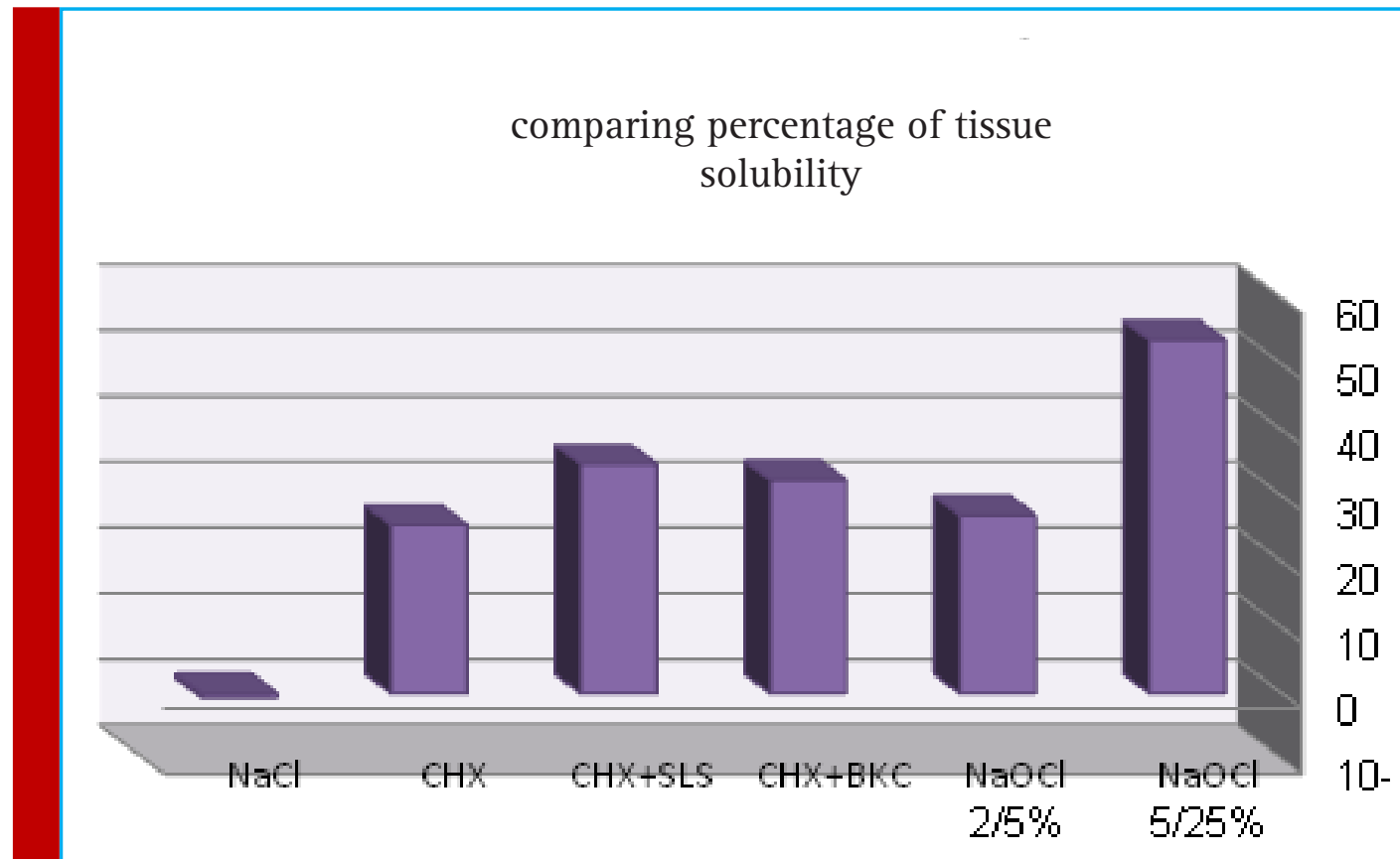

DIAGRAM 7. Root dentine section which is covered with smear layer resulted from canal working tools

Table 3. descriptive statistics

\begin{tabular}{|l|l|l|l|l|l|l|l|l|}
\hline & \multirow{2}{*}{$\mathrm{N}$} & \multirow{2}{*}{ Mean } & $\begin{array}{l}\text { Std. } \\
\text { Deviation }\end{array}$ & \multirow{2}{*}{ Std. Error } & \multicolumn{2}{|l|}{ 95\% Confidence Interval for Mean } & Minimum & Maximum \\
\cline { 6 - 8 } & & & & Lower Bound & Upper Bound & & \\
\hline 1 & 10 & 1.3470 & .50193 & .15872 & .9879 & 1.7061 & .57 & 2.20 \\
\hline 2 & 10 & .6710 & .64264 & .20322 & .2113 & 1.1307 & -.89 & 1.28 \\
\hline 3 & 10 & .8180 & .34902 & .11037 & .5683 & 1.0677 & .38 & 1.44 \\
\hline 4 & 10 & .8780 & .20460 & .06470 & .7316 & 1.0244 & .51 & 1.08 \\
\hline 5 & 10 & .6570 & .17353 & .05487 & .5329 & .7811 & .31 & .89 \\
\hline 6 & 5 & -.0180 & .23221 & .10385 & -.3063 & .2703 & -.40 & .20 \\
\hline Total & 55 & .7728 & .50398 & .06251 & .6479 & .8977 & -.89 & 2.20 \\
\hline
\end{tabular}

Table 4. ANOVA analysis

\begin{tabular}{|l|l|l|l|l|l|} 
& $\begin{array}{l}\text { Sum of } \\
\text { Squares }\end{array}$ & df & $\begin{array}{l}\text { Mean } \\
\text { Square }\end{array}$ & F & Sig. \\
\hline Between Groups & 6.918 & 6 & 1.153 & 7.161 & .000 \\
\hline Within Groups & 9.338 & 58 & .161 & & \\
\hline Total & 16.256 & 64 & & & \\
\hline
\end{tabular}

Table 5. HVariances analysis

\begin{tabular}{|l|l|l|l|}
\hline Levene Statistic & df1 & df2 & Sig. \\
\hline 3.085 & 6 & 58 & .011 \\
\hline
\end{tabular}


Table 6. Welch analysis

\begin{tabular}{l|l|l|l|l|} 
& Statistica & df1 & df2 & Sig. \\
\hline Welch & 10.749 & 6 & 23.054 & .000 \\
\hline
\end{tabular}

a. Asymptotically F distributed. clean complex tubular networks of canal (Mehrvarzfar and Saghiri 2011). So using detergents along with mechanical preparation is needed (Tirali et al, 2013; Torabinejad et al, 2003). These materials complete mechanical debridement by flushing out debris, solving necrosis tissues, removing smear layer, and disinfection

\begin{tabular}{|c|c|c|c|c|c|c|}
\hline \multirow[t]{2}{*}{ (I) group } & \multirow[t]{2}{*}{ (J) gruop } & \multirow{2}{*}{$\begin{array}{l}\text { Mean Difference } \\
\text { (I-J) }\end{array}$} & \multirow[t]{2}{*}{ Std. Error } & \multirow[t]{2}{*}{ Sig. } & \multicolumn{2}{|c|}{ 95\% Confidence Interval } \\
\hline & & & & & Lower Bound & Upper Bound \\
\hline \multirow{5}{*}{1} & 2 & .67600 & .25786 & 315 & -.2405 & 1.5925 \\
\hline & 3 & .52900 & .19333 & 266 & -.1650 & 1.2230 \\
\hline & 4 & .46900 & .17140 & 320 & -.1870 & 1.1250 \\
\hline & 5 & $.69000^{*}$ & .16794 & .035 & .0355 & 1.3445 \\
\hline & 6 & $1.36500^{*}$ & .18968 & .000 & .6542 & 2.0758 \\
\hline \multirow{5}{*}{2} & 1 & -.67600 & .25786 & .315 & -1.5925 & 2405 \\
\hline & 3 & -.14700 & .23126 & 1.000 & -1.0011 & .7071 \\
\hline & 4 & -.20700 & .21327 & 1.000 & -1.0448 & .6308 \\
\hline & 5 & .01400 & .21050 & 1.000 & -.8244 & .8524 \\
\hline & 6 & .68900 & .22822 & 196 & -.1756 & 1.5536 \\
\hline \multirow{5}{*}{3} & 1 & -.52900 & .19333 & .266 & -1.2230 & 1650 \\
\hline & 2 & .14700 & .23126 & 1.000 & -.7071 & 1.0011 \\
\hline & 4 & -.06000 & .12794 & 1.000 & -.5281 & 4081 \\
\hline & 5 & .16100 & .12326 & 994 & -.2994 & .6214 \\
\hline & 6 & $.83600^{*}$ & .15154 & .003 & 2517 & 1.4203 \\
\hline \multirow{5}{*}{4} & 1 & -.46900 & .17140 & .320 & -1.1250 & 1870 \\
\hline & 2 & .20700 & .21327 & 1.000 & -.6308 & 1.0448 \\
\hline & 3 & .06000 & .12794 & 1.000 & -.4081 & .5281 \\
\hline & 5 & .22100 & .08484 & .320 & -.0790 & .5210 \\
\hline & 6 & $.89600^{*}$ & .12235 & .003 & .3396 & 1.4524 \\
\hline \multirow{5}{*}{5} & 1 & $-.69000^{*}$ & .16794 & .035 & -1.3445 & -.0355 \\
\hline & 2 & -.01400 & .21050 & 1.000 & -.8524 & .8244 \\
\hline & 3 & -.16100 & .12326 & .994 & -.6214 & . 2994 \\
\hline & 4 & -.22100 & .08484 & 320 & -.5210 & .0790 \\
\hline & 6 & $.67500^{*}$ & .11745 & .021 & . 1043 & 1.2457 \\
\hline \multirow{5}{*}{6} & 1 & $-1.36500^{*}$ & .18968 & .000 & -2.0758 & -.6542 \\
\hline & 2 & -.68900 & .22822 & . 196 & -1.5536 & 列 .1756 \\
\hline & 3 & $-.83600^{*}$ & .15154 & .003 & -1.4203 & -.2517 \\
\hline & 4 & $-.89600^{*}$ & .12235 & .003 & -1.4524 & -.3396 \\
\hline & 5 & $-.67500^{*}$ & .11745 & .021 & -1.2457 & -.1043 \\
\hline
\end{tabular}


of root canal system. There is no single solution that can do all these (Rossi-Fedele, et al, 2012).

Our ai mis quantitative comparaison of tissue solubiity of $\mathrm{NaOCl}$ solutions and converted chlorhexidine. Solution under-study in This resarci inclue NaOCl 25/5\%, $\mathrm{NaOCl} 5 / 2 \%$, CHX2/0\%, CHX+BKCandCHX+SLS. sodium hypochlorite is mostly used in root treatment however toxicity of this material for pri apical tissues is remained as a basic concern (Cobankara et al, 2010). Chlorhexidine was selected due to anti-microbial properties, less toxicity than $\mathrm{NaOCl}$, biocompatibility, and its stability of the experiment. But it is proved that (Arcangelo, 2007) this material has no acceptable capacity in high densities for solving organic tissue so two type of surfactants were added ito CHX in order to increase solubility.

Results indicated that maximum solubility is related to $5 / 25 \%$ sodium hypochlorite and average negative tissue solubility was related to normal saline. After25/5\%NaOCl, CHX+SLS had maximum tissue solubility. Statistical analysis of ANOVA with 95\% as confidence level was performed by 6 groups. And $p<0 / 05$ indicates that there is no signifiant différence $(\mathrm{P}=0 / 0)$. In addition, in Hemogeneity of variances test $(\mathrm{P}<0.05)$, variance of 6 group, has significant difference $(\mathrm{P}=0.011)$.

For comparing 6 group median, Welch test was used in which significant difference was observed in groups $(\mathrm{P}=0.0)$. for pairwise comparison of groups, Tamhane was used. As there is no similar research in this case we tested all solutions separately. In this study, average solubility was related to $\mathrm{NaOCl} 25 / 5 \%$ and $5 / 2 \%$ which was respectively $7 / 53 \%$ and $07 / 27 \%$ while there was no significant difference in both group considering solubility $(\mathrm{P}=315)$. In addition, 25/5\% $\mathrm{NaOCl}$ had maximum tissue solubility. This case is compatible with Cobankara et al (2010), Cbristensen et al (2008), Arcangelo et al (2007), Naenni et al (2004), Okino et al (2004), Turkun et al (1997), Hand et al (1998).

\section{CONCLUSION}

25/5\% $\mathrm{NaOCl}$ had maximum tissue solubility. Other than 0/2\% CHX and normal saline. Considering tissue solubility, there is no significant difference in other solution with $\mathrm{NaOCl} 25 / 5$. Consequently, based on this research using SLS 2\% CHX+ 2/0\% in canal washing can have similar effect as $\mathrm{NaOCl}$ 25/5\% regarding solubility.

\section{REFERENCES}

Arcangelo C, Di Nardo Di Maio F, Stracci N, Spoto G, Malagnino VA, Caputi S. (2007). Pulp-dissolving ability of several endodontic irrigants: a spectrophotometric evaluation. Int JIP; 20(2): 381.
Aulton M, Taylor K. (2008). Aulton's Pharmaceutics: The Design and Manufacture of Medicines. Thed.537-540.

Baumgartner JC, Johal S, Marshall JG. (2007). Comparison of the antimicrobial efficacy of $1.3 \% \mathrm{NaOCl} /$ biopure MTAD to $5.25 \% \mathrm{NaOCl} / 15 \%$ EDTA for root canal irrigation. JOE; 33(1): 47-51.

Beltz RE, Torabinejad M, pouresmail M. (2003). Quantitative analysis of the solubilizing action of MTAD, sodium hypochlorite, and EDTA on bovine pulp and dentin. J Endod; 29(5): 334-337.

Christensen CE, F. McNeal S, Eleazer P. (2008). Effect of Lowering the $\mathrm{pH}$ of Sodium Hypochlorite on Dissolving Tissue in Vitro. JOE. Apr; 34(4):449-452.

Clarkson RM, Moule AJ, Podlich H, Kellaway R, Macfarlane R, Lewis D, Rowell J. (2006). Dissolution of porcine incisor pulps in sodium hypochlorite solutions of varying compositions and concentrations. Aust Dent J. Sep;51(3):245-51.

Cobankara FK, Ozkan HB, Terlemez A. (2010). Comparison of organic tissue dissolution capacities of sodoum hypochlorite and chlorine dioxide. JOE; 36(2): 272-274.

Effendy I, I. Maibach H. (1995). Surfactants and experimental irritant contact dermatitis. Contact Dermatitis Oct; 33(4): 217-225.

E. Hand R, L. Smith M, W. Harrison J. (1998). Analysis of the Effect of Dilution on theNecrotic Tissue Dissolution Property ofSodium Hypochlorite. JOE Feb;4(2):60-64.

E. Vianna M, P. F. A. Gomes B. (2009). Efficacy of sodium hypochlorite combined with chlorhexidine against Enterococcus faecalis in vitro. Oral Surg Oral Med Oral Pathol Oral Radiol Endod; 107:585-589.

Guerreiro-Tanomaru JM, Morgental RD, Faria-Junior NB, Berbert FLCV, Tanomaru-Filho M. (2011). Antibacterial effectiveness of Peracetic Acid and conventional endodontic irrigants. Braz Dent J; 22(4): 285-287.

Ibusquiza PS, J.R. Herrera J, Vázquez-Sánchez D, Parada A, L. Cabo M. (2012). A new and efficient method to obtain benzalkonium chloride adapted cells of Listeria monocytogenes. Journal of Microbiological Methods. 91:57-61.

Iqbal A. (2012). Antimicrobial Irrigants in the Endodontic Therapy. International Journal of Health Sciences; 6(2): 153158.

Irala LE, Grazziotin-Soares R, Salles AA, Munari AZ, Munari JS. (2010). Dissolution of bovine pulp tissue in solutions consisting of varying $\mathrm{NaOCl}$ concentrations and combined with EDTA. Braz Oral Res. Jul-Sep;24(3):271-6.

J. Kleier D, E. Averbach R, Mehdipour 0. (2008). The Sodium Hypochlorite Accident: Experience of Diplomates of the American Board of Endodontics. JOE Nov;34(11):1346-50.

Johnson W T, Noblett W C. (2008). Cleaning \& shaping. In: Torabinejad M, Torabinejad M. Principles \& practice endodontics. 4thed.287-315.

Kandaswamy D, Venkateshbabu N. (2010). Root canal irrigants. J Conserv Dent; 13(4):256-264. 
Karale R, Thakore A, Shetty VK. (2011). An evaluation of antibacterial efficacy of 3\% sodium hypochlorite, high-frequency alternating current and 2\% chlorhexidine on Enterococcus farcalis: An in vitro study. J Conserv Dent; 14:2-5.

Krithikadatta J, Indira R, Dorothykalyani AL. (2007). Disinfection of dentinal tubules with 2\% chlorhexidine, $2 \%$ metronidazole, bioactive glass when compared with calcium hydroxide as intracanal medicaments. JOE; 33(12): 1473-1476.

Lee HL, I. Maibach H. (1996). Sodium Lauryl Sulfate. Contact Dermatitis 0ct;35(4):257-267.

Marple B, Ronald P, Benninger M. (2004). Safety review of benzalkonium chloride used as a preservative in intranasal solutions: An overview of conflicting data and opinions. Otolaryngology-Head and Neck Surgery; 130(1):131-41.

Martin H. (1991). Cleanliness, disinfection, and sterilization of the root canal. Curr Opin Dent. 1991 Dec;1(6):734-436.

Mohammadi Z, Abbott PV. (2009). The properties and applications of chlorhexidine in endodontics. Int Endod J. Apr;42(4):288-302.

M. Sassone L, Fidel RAS, Murad CF, Fidel SR, Hirata Jr R. (2008). Antimicrobial activity of sodium hypochlorite and chlorhexidine by two different tests. Aust Endod J; 34: 19-24.

Naenni N, Thoma K, Zehnder M. (2004). Soft tissue dissolution of currently used and potential endodontic irrigants. J Endod; 30(11):785-787.

Neppelberg E, Costea DE, Vintermyr OK, Johannessen AC. (2007). Dual effects of sodium lauryl sulphate on human oral epithelial structure. Experimental Dermatology. 16:574-579.

Okino LA, Siqueira EL, Santos M, Bombana AC, Figueiredo JA. (2004). Dissolution of pulp tissue by aqueous solution of chlorhexidine digloconate and chlorhexidine digloconate gel. Int Endod J; 37(1): 38-41.

Parirokh M, Jalali S, Haghdoost AA, Abbott JV. (2012). Comparison of the Effect of Various Irrigants on Apically Extruded Debris after Root Canal Preparation.JOE Feb;38(2): 196199.

Paudel K R, Jaiswal A, Parajuli U, Bajracharya M. (2011). Different pharmacological solutions in intracanal irrigation. Nepal Med Coll J; 13(2): 111-114.

Portenier I, Haapasalo H, Ørstavik D, Yamauchi M, Haapasalo M. (2002). Inactivation of the Antibacterial Activity of Iodine Potassium Iodide and Chlorhexidine Digluconate Against Enterococcus faecalis by Dentin, Dentin Matrix, Type-I Collagen, and Heat-Killed Microbial Whole Cells. JOE. Sep; 28(9):634637.

Regan JD, Fleury A A. (2006). Irrigants in non-surgical endodontic treatment. J Ir Dent Assoc. Autumn;52(2):84-92.

Rossi-Fedele G, Doğramac E J, Guastalli A R, Steier L, Poli de Figueiredo J A. (2012). Antagonistic Interactions between Sodium Hypochlorite, Chlorhexidine, EDTA, and Citric Acid. JOE; 38(4): 426-431.

Saber S, Hashem A. (2011). Efficacy of different final irrigation activation techniques on smear layer removal. JOE; 37(9): 1272-1275.

Sajadi tabassi S.A, Mamaghani sani D. (1996). Investigation of the effects of ionic surfactants on biological membranes using human erythrocytes as a model. Contact Dermatitis 0ct;35(4):253-256.

Siqueira J F, Rôças I N, Favier I A, Lima K C. (2009). Efficacy of Instrumentation Techniques and Irrigation Regimens in Reducing the Bacterial Population within Root Canals. JOE.; 27(7): 236-237.

TiraliR E, Bodur H, Sipahi B, Sungurtekin E. (2013). Evaluation of the antimicrobial activities of chlorhexidine gluconate, sodium hypochlorite and octenidine hydrochloride in vitro. Aust Endod J; 39: 15-18.

Torabinejad M, Khademi A A, Babagoli J, Cho Y, Johnson W B, Bozhilov K. (2003). A New Solution for the Removal of the Smear Layer. JOE; 29(3): 170-175.

Turkun M, Cengiz T. (1997). The effect of sodium hypochlorite and calcium hydroxide on tissue dissolution and root canal cleanliness. Int Endod J; 30(5): 335.

VS Hariharan, B Nandlal, KT Srilatha. (2010). Efficacy of various root canal irrigants on removal of smear layer in the primary root canals after hand instrumentation: A scanning electron microscopy study. J Indian Soc Pedod Prev Dent; 26(4): 271-277.

Zehnder M. (2006). Root Canal Irrigants. JOE May;32(5):38998.

Zehnder M, Grawehr M, Grawehr G, Waltimo T. (2003). Tissuedissolution capacity and dentin-disinfecting potential of calcium hydroxide mixed with irrigating solutions. Oral Surg Oral Med Oral Pathol Oral Radiol Endod; 96: 608-612.

Zhang C, Tezel U, Li K, Liu D, Ren R, Du J (2011). Evaluation and modeling of benzalkonium chloride inhibition and biodegradation in activated sludge. Water Research. 45: 1238-1246. 